\title{
Influence of oceanic-atmospheric interactions on extreme events of daily rainfall in the Sub-basin 39 located in Northeastern Brazil
}

\section{Influência da interação oceânico-atmosférica nos eventos extremos de precipitação diária na Sub-bacia 39, localizada no Nordeste do Brasil}

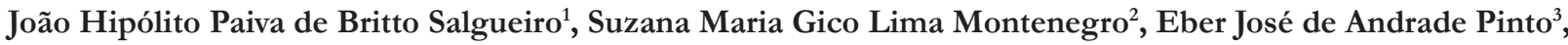 \\ Bernardo Barbosa da Silva², Werônica Meira de Souza ${ }^{4}$ and Leidjane Maria Maciel de Oliveira ${ }^{2}$ \\ ${ }^{1}$ Serviço Geológico do Brasil, Recife, PE, Brazil \\ ${ }^{2}$ Universidade Federal de Pernambuco, Recife, PE, Brazil \\ ${ }^{3}$ Serviço Geológico do Brasil, Belo Horizonte, MG, Brazil \\ ${ }^{4}$ Universidade Federal Rural de Pernambuco, Garanhuns, PE, Brazil \\ E-mails: joao.salgueiro@cprm.gov.br (JHPBS), suzanam.ufpe@gmail.com (SMGLM), eber.andrade@cprm.gov.br (EJAP), \\ bbdasilva.ufpe@gmail.com (BBS),weronicameira@gmail.com (WMS), leidjaneoliveira@hotmail.com (LMMO)
}

Received: December 16, 2015 - Revised: May 28, 2016 - Accepted: June 14, 2016

\begin{abstract}
Changes in extreme precipitation have been observed in regions where frequent rainfalls occur over short periods of time followed by prolonged droughts, creating, as a result, new watershed scenarios. Recent studies have attributed such occurrences to possible climate changes. This paper analyzes the correlation between extreme events recorded in the Sub-basin 39, located in Northeastern Brazil, and the anomalies caused by sea surface temperature - SST and the atmospheric systems operating in the region. Pearson correlation coefficients have been used combined with the variables analyzed. For such, trends in precipitation have been obtained by using the method of least squares together with linear regression and the Student's $t$ test. The results obtained have demonstrated that due to the geographical position of the region investigated, both maximum extreme events (areas with positive trends) and minimum extreme events (areas with negative trends) are more dependent on the Dipole Atlantic than on the effects of El Niño Southern Oscillation - ENOS.
\end{abstract}

Keywords: Climate change; Maximum precipitation; Minimum precipitation; Influence on TSM.

\section{RESUMO}

As alterações nos extremos pluviométricos estão sendo observadas em várias localidades, com uma frequência maior de chuvas intensas concentradas em poucos dias e estiagens mais prolongadas, passando a caracterizar novos cenários nas bacias hidrográficas. Estudos específicos vêm atribuindo tais ocorrências às possíveis modificações climáticas. Este artigo analisou a relação existente entre os eventos extremos registrados na Sub-bacia 39, localizada no Nordeste do Brasil, com as anomalias das Temperaturas da Superfície do Mar (TSM) e os sistemas atmosféricos atuantes na região, utilizando os coeficientes de correlação de Pearson entre as variáveis analisadas. Para isso, as tendências da precipitação foram obtidas utilizando o Método dos Mínimos Quadrados, associado à regressão linear e o teste $t$ de Student. Os resultados evidenciaram que devido à posição geográfica da região estudada, tanto os eventos extremos máximos (áreas com tendências positivas) como os eventos extremos mínimos (áreas com tendências negativas) são bem mais dependentes do Dipolo do Atlântico do que das influências do El Niño/Oscilação Sul - ENOS.

Palavras-chave: Mudanças climáticas; Precipitações máximas; Precipitações mínimas; Influência de TSM. 


\section{INTRODUCTION}

Climate change has become the main topic of discussion in recent decades. Global warming and its various consequences, including changes in rainfall, have attracted researchers' attention worldwide (SILVA et al., 2015). According to Santos et al. (2014), climate warming over the past few years may be attributed to changes in the components of both the hydrological cycle and the hydrological system, such as precipitation patterns. Farias and Nóbrega (2010) reported that extreme events, like severe droughts or excessive flooding, can cause serious problem to the public at large, bringing about floods in huge urban areas and prolonged droughts in rural areas.

The IPCC (2013), on its fifth Activity Report, investigates further the present topic, including the part related to Northeastern Brazil. This is the case of disuniformities along the hydrologic cycle in response to global warming in the twenty-first century: rainfall increased contrast between wet and dry regions; and the likely increase in intensity and frequency of maximum extreme precipitation events over greater part of the humid tropics.

Farias and Nóbrega (2010) showed a tendency towards increased rainfall in greater part of the State of Pernambuco. On the other hand, Santos et al. (2014) noticed a reduction in rainfall in the Una river basin in Pernambuco. Also in the same State, reduced rainfall was observed to occur in the Brigida and Pajeú river basins along the Hinterland. Reduced rainfall was also noticed in the Capibaribe basin in the Agreste, according to Assis, Sobral and Souza (2012), and Assis and Sobral (2012), respectively. Souza and Azevedo (2012) observed an increase in heavy rainfalls in Recife.

According to Araújo and Brito (2011), the Northeast Brazil (NEB) has its climate variability related to varying patterns at global scale. Such patterns have been associated with thermal fluctuations over the Pacific and Atlantic oceans. In the Pacific Ocean, the oceanographic phenomenon ElNiño causes variations and periodic fluctuations at seasonal and inter-annual scales as a result of the interaction between the ocean and the atmosphere. On the other hand, the tropical Atlantic Ocean is characterized by a strong seasonal pattern that manifests itself mainly as a southern shift of the Inter Tropical Convergence Zone (ITCZ). Menezes et al. (2008) added that the ENSO (El Niño Southern Oscillation) and the Tropical Atlantic Dipole directly affect the position of the ITCZ which, in turn, influences the distribution of rainfall over the NEB.

According to Mendonça and Danni-Oliveira (2007), El Niño is a phenomenon characterized by the anomalous warming of surface waters in the central and eastern part of the Pacific Ocean, near South America, more particularly along the Peruvian coast. The anti-ElNiño, also called La Niña, is represented by the unusual cooling of the Pacific waters. As observed by Cavalcanti et al. (2009), during El Niño, the sea surface temperature (SST) over the Equatorial Pacific Ocean, both Central and East, is warmer than usual, increasing, as a result, the atmospheric convection in these regions. Cavalcanti et al. (2009) have also observed that, in the Western Pacific, where convection and precipitation decrease, the TSM cools off.

Marcuzzo and Romero (2013) considered that both ElNiño and La Niña play a significant role in the temporal distribution of anomalies during maximum daily rainfall, causing either an increase or decrease of rain along periods of sharp changes in the average temperature of the Pacific Ocean. According to Sousa et al. (2015), the impact of the ElNiño (La Niña) - depending on its intensity can cause severe droughts (floods), producing a significant impacts on the Northern/Northeastern Brazil economy.

Ferreira and Mello (2005) observed that ElNiño is responsible for the dry years or the very dry years in the NEB, mainly when it comes in combination with the Atlantic positive dipole which is most unfavorable to rainfall. La Niña, on the other hand, is associated to the negative dipole of the Atlantic, which is most favorable to rainfall. This phenomenon is usually responsible for the years considered normal, rainy or very rainy in the region. In years with positive or negative SST anomalies, the Hadley cell, which runs southernwards (the ascending branch of the tropics and the descending branches of the subtropics) and the Walker cell, which runs in zonal direction (the ascending branch in the western Pacific and the descending branch in the eastern Pacific) may be disturbed, causing strong anomalies in the atmospheric circulation over the tropics, since these cells are displaced from their climatological positions, affecting the intensity and duration of the rainy season.

According to Cavalcanti et al. (2009), the anomalous SST gradient between the Tropical North Atlantic and the Tropical South Atlantic affects rainfall in the NEB. This is because it acts on the position of the ITCZ which controls the rainy season in the region. Moura et al. (2009) state that the current knowledge of the Atlantic dipole, together with information on ENSO episodes help implement better rainfall predictions in the NEB.

As observed by Santos and Brito (2007) and Santos and Manzi (2011), the SST negative anomalies (positive) over the North Atlantic Ocean, and the positive (negative) anomalies over the South Atlantic Ocean, produced the displacement of the ITCZ southwards (northwards), favoring rainfall events (inhibition of rain) on the NEB. Moura et al. (2009) noticed that, when the ITCZ takes place in the northern hemisphere, it exhibits an SST much warmer than usual. This favors the occurrence of drought in the NEB. When the ITCZ is found further south, along the coast of the NEB, the water becomes hotter than normal. This implies that precipitation is above the climatological average for the NEB.

The present work is based on the presence of an increased rate of occurrence and on the magnitude of extreme precipitation events in recent years as observed in the eastern sector of the NEB, where the Sub-basin 39 is located. The main goal of our study is to define the influence of ElNiño/Southern Oscillation (ENSO) and that of the Atlantic Dipole on the maximum and minimum daily extreme precipitations on the NEB sector. All results obtained here represent an important scientific contribution to both researchers and institutions worldwide; leading to studies whose main objective will be to implement a better understanding of these phenomena. Moreover, the management of water resources and security systems to benefit the Sub-basin 39 population will be most vital, since rainfalls are getting scarcer, or otherwise they hit the region with such an impact so as to cause severe floods, endangering entire cities (MARENGO et al., 2011). 


\section{MATERIAL AND METHODS}

\section{Characterization of the study area}

According to Salgueiro et al. (2014), the Sub-basin 39 is located in the eastern part of the Northeast Atlantic River Basin, which is one of the 12 components of the National Hydrographic Division established by Resolution No. 32 of the National Water Resources Council - CNRH in 2003. This river basin district $(\mathrm{RH})$ is located in the NEB and is made up of 5 sub-basins. The sub-basin 39 embodies 3\% of the State of Paraiba, $66 \%$ of the State of Pernambuco and $31 \%$ of the State of Alagoas, as shown in Figure 1.

The Sub-basin 39 occupies an area of $43,183 \mathrm{~km}^{2}$, with a population of 9,257,696 inhabitants, according to the 2010 census of the Brazilian Institute of Geography and Statistics (IBGE) (Salgueiro et al., 2014). The zonal division of climates in Brazil includes the Sub-basin 39 as part of the Climate Tropical Eastern Northeast, featuring "hot climate" in greater part of its territory with small occurrences of "subquente Climate" (IBGE, 2014). The Sub-basin 39 is geographically divided into the following sections: Litoral, Mata and Agreste. The first two sections have the highest rainfall totals, while the third, with an intermediate region in between the moist warm areas (Litoral and the Zona da Mata) and semiarid (Hinterland), presents zonal climate similarities

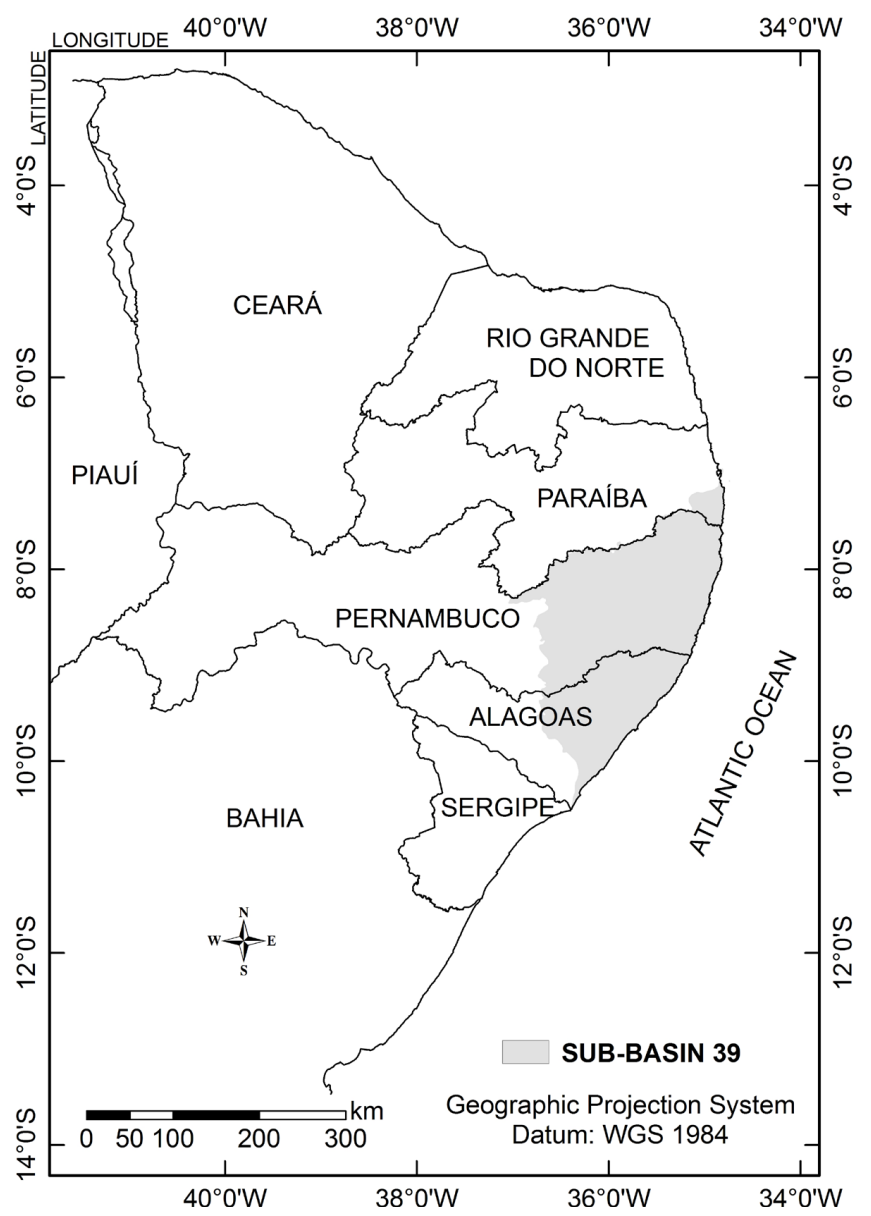

Figure 1. Location of the Sub-basin 39 in the NEB. to those two forms (PERNAMBUCO, 2006). In the Agreste, the semi-arid climate stands out in the Middle Capibaribe and near the São Francisco river basin.

The weather phenomena actuating in the Sub-basin 39 are the same as those found in the NEB. According to Wanderley et al. (2013), the distribution of rainfall in the NEB is influenced by the interaction of both Pacific and Atlantic Oceans; such is the case of the Pacific decadal Oscillation, the Atlantic Dipole and the ENSO. As regards the rain-inducing weather systems in the region, one may call attention to the following: the ITCZ, the frontal systems, squall lines, cyclonic vortices at high levels, wavelike disturbances or the easterly waves and convective complexes in meso-scale. For SECTMA (PERNAMBUCO, 2006), the ITCZ represents the main rainfall producing system in the semiarid region. It operates mainly in the months of March and April. In some years, it occurs in February and May. The easterly waves, which form over the Atlantic Ocean, reach the coast and the forest zone bringing about heavy rains in the period that extends from May to August.

As to the region's geomorphology, the "Eastern Plateau of Borborema" extends throughout the western Sub-basin 39 (IBGE, 2014). According to SECTMA (PERNAMBUCO, 2006), in the east-west direction along the Pernambuco section, the coastal plain anticipates the hills and savannas, which in turn precede the plateaus with altitudes that reach up to $800 \mathrm{~m}$. Rainfall is influenced by these heights as a result of strong orographic effects.

\section{Network monitoring and data consistency}

As regards quality criteria, length of period and location of points of measurement on time series, 16 conventional rain gauge stations were selected in order to set up a rainfall network over the Sub-basin 39 (Figure 2).

Nevertheless, the data obtained from the following official bodies have been examined: Pernambuco Agency of Water and Climate / Institute of Technology of Pernambuco (APAC / ITEP), the National Institute of Meteorology (INMET) and the National Water Agency / Geological Survey of Brazil (ANA / CPRM). Based on these data, it was possible to build up a specific database to support the present research, in which periods of daily observation of 70 years dated from 1943 until 2012 have been considered.

For the consistency of all the data derived from the time series (homogenization and gap fillings), the Methods of Multiple Linear Regression and Dual-mass were employed. Afterwards, all series were subjected to statistics and exploratory analyzes, mainly to check for the presence of outliers and precipitation trends.

\section{Punctual rainfall indices}

In order to determine the trends at each rainfall station, version 2.14.1 of the RClimdex software was used. This program was created in 2004 to do the calculation of indices of climate extremes as proposed by the Expert Team on Climate Change Detection, Monitoring and Indices (EETCCDMI). The program was made available by the World Meteorological Organization (WMO, 2009). From all climatic indices made available by this program, nine rainfall indices were selected. These were obtained 
from the daily series of annual rainfall in each season. These indices have been recommended and fully described by Zhang and Yang (2004) in Table 1.

The RClimdex program together with the climate indices recommended by the World Meteorological Organization (WMO) have been widely used at all scales to detect precipitation trends. In Brazil, some studies can be cited, such as: Santos et al. (2012a), who applied to the part of Northern Brazil, including the North, Northeast, Midwest and part of the Southeast; Santos et al. (2012b) applied to Manaus; Pinheiro, Graciano and Severo (2013) in southern

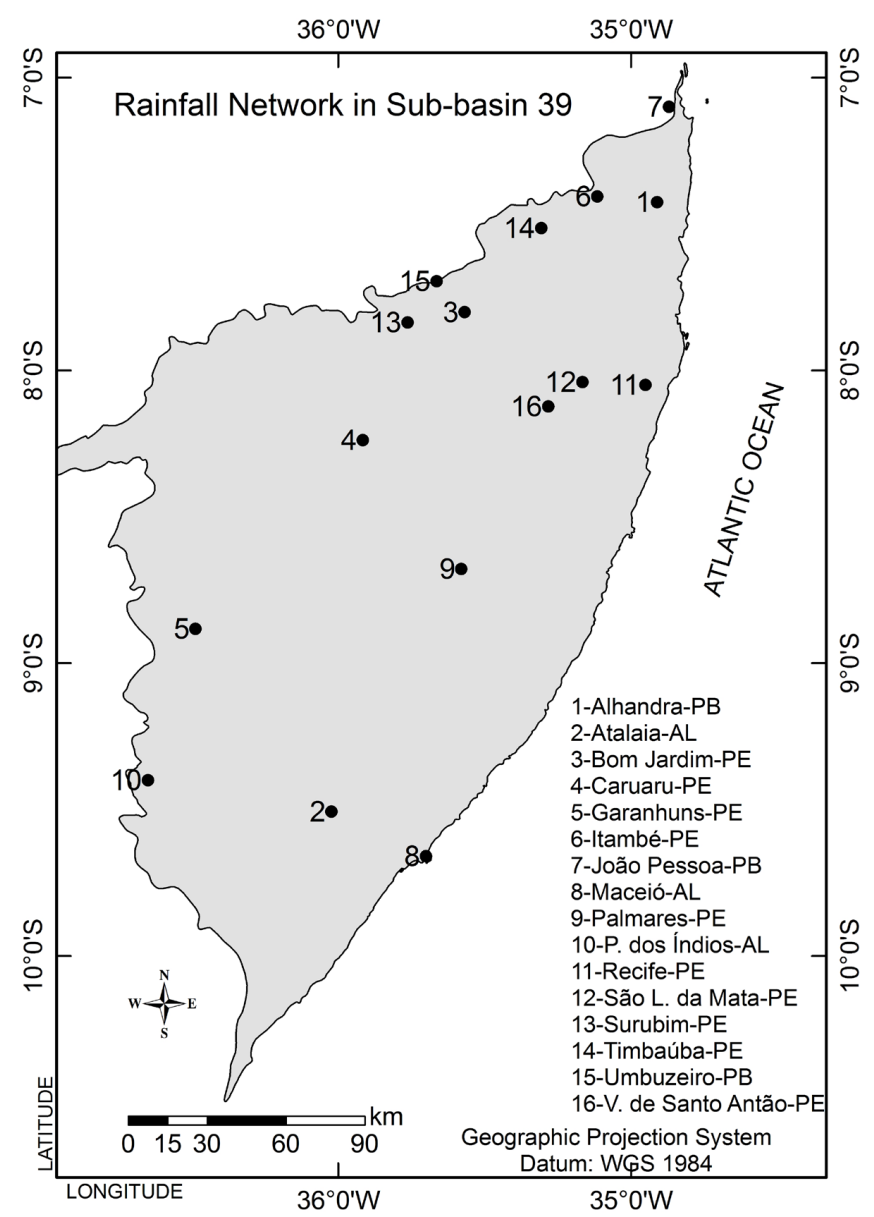

Figure 2. Spatial distribution network.

Table 1. Pluviometric index used.

\begin{tabular}{|c|c|}
\hline Index & Definition / Unit \\
\hline PRCPTOT & Total annual precipitation in wet days $(\mathrm{mm})$ \\
\hline RMedmm & $\begin{array}{l}\text { Number of days with greater precipitation than or } \\
\text { equal to the median (days) }\end{array}$ \\
\hline RX1day & Maximum height precipitation in one day (mm) \\
\hline RX5day & Maximum Height precipitation in five days ( $\mathrm{mm}$ ) \\
\hline SDII & Simple index daily intensity (mm) \\
\hline R10mm & $\begin{array}{l}\text { Number of days with precipitation less than } 10 \mathrm{~mm} \\
\text { (days) }\end{array}$ \\
\hline $\mathrm{R} 50 \mathrm{~mm}$ & $\begin{array}{l}\text { Number of days with precipitation less than } 50 \mathrm{~mm} \\
\text { (days) }\end{array}$ \\
\hline R99p & $\begin{array}{l}\text { Total annual precipitation of extremely wet days } \\
(\mathrm{mm})\end{array}$ \\
\hline CWD & Maximum number of consecutive wet days (days) \\
\hline
\end{tabular}

Brazil; Santos et al. (2012c) applied to the city of Rio Claro, São Paulo; Wang et al. (2012, 2013) and Jiang et al. (2013) applied to China, and Santos et al. (2011, 2012d) who applied to Utah and Idaho, USA.

The program can assess data quality and uses a linear Regression Method associated with the least-squares. The main statistical data provided for each calculated index are: the trend set by the slope of the line (slope coefficient); the level of statistical significance of the trend obtained by the test "Student's t"; the coefficient of determination $\left(\mathrm{R}^{2}\right)$; and the standard error of estimate (EPE).

To confirm the presence of a tendency (positive or negative) in the series, one should verify initially whether the tendency obtained is higher than the standard error of estimate. At the same time, one should evaluate its statistical significance. At the same time statistical significance is evaluated. According to Zhang and Yang (2004), the trend will be significant if $\mathrm{p}<0.10$. When $\mathrm{p}>0.10$, it can be said that the trends are not statistically significant and that there are no trends in the series.

\section{Regional rainfall indices}

Based on the increasing and decreasing results derived from statistically important indices resulting from each rainfall series processed in the Sub-basin 39, a bipolar separation of these trends regarding each index was applied: on one side, the set of positive trends, and on the other, the set of negative trends over each index. In order to provide regional representation for each index (positive and / or negative), the arithmetic average of all indices on each set-point was calculated. The selection of biased results caused the formation of the indices obtained at the Sub-basin 39, such as: "positive regional trend indices" and "negative regional trend indices". These indices will be given different representations by means of underlines.

\section{SST anomalies indices}

The Pacific and Atlantic Oceans indices were provided by the National Oceanic and Atmospheric Administration (NOAA, 2014). The indices used and their corresponding oceanic regions are: a) Niño $1+2$ - in the western part of the ocean close to the equatorial Pacific coast of Peru in South America.

b) Niño 3 - between regions Niño $1+2$ and Niño 3.4 in the equatorial Pacific Ocean.

c) Niño 3.4 - the central portion of the equatorial Pacific Ocean between South America and the Australian continent.

d) Niño 4 - in the western part of the ocean close to the equatorial Pacific near the Australian continent.

e) Southern Oscillation Index (SOI) - between the Australian islands of Tahiti and Darwin in the equatorial Pacific Ocean.

f) Index Oceanic Niño (ION) - in the Niño 3.4 region of the equatorial Pacific Ocean.

g) Tropical North Atlantic Index (TNAI) - in the northern part of the Atlantic Ocean or above the equator.

h) The Tropical North Atlantic Index (TSAI) - in the southern portion of the Atlantic Ocean or below the equator. 


\section{Determining the correlation coefficients}

The "Pearson Method" was used to calculate all linear correlations. The method was applied to both positive and negative regional trends and to the indices of SST anomalies given by NOAA (2014). Then, the resulting data were evaluated as to their statistical significance of $1 \%, 5 \%$ and $10 \%$ and degree of freedom (n-2). For this, test statistics and critical values were determined. Rejections of the null hypothesis $\mathrm{h}_{0}$ revealed the existence of a linear correlation between some of these combinations. According to Naguettini and Pinto (2007), the linear correlation coefficient can be represented by $\varrho$. The variables $\mathrm{X}$ and $\mathrm{Y}$ are statistically independent, consequently one would expect that $\varrho=0$. To test the hypothesis that the correlation coefficient is equal to zero, it should be taken that: $\mathrm{H}_{0}: \rho=0$ and $\mathrm{H}_{1}: \rho \neq 0$. The appropriate statistics for this test is:

$t_{0}=\frac{r \sqrt{n-2}}{\sqrt{1-r^{2}}}$

where $t_{0}$ is the test statistic; $n$ is the sample size and $r$ is the estimate of the correlation coefficient. Under the assumption of the null hypothesis $\mathrm{H}_{0}: \rho=0$. The null hypothesis is rejected if:

$\left|t_{0}\right|>t_{\alpha / 2(n-2)}$

where, $t_{\alpha / 2(n-2)}$ is the critical value for the statistical significance level test $\alpha$.

\section{RESULTS AND DISCUSSION}

\section{SST influence on maximum extreme events}

Table 2 shows Pearson linear correlation coefficients resulting from adjustments between the indices of the SST anomalies and the rates of positive regional trends calculated for Sub-basin 39. Significant statistical correlations have demonstrated that precipitation with positive trends, as detected at Sub-basin 39, is far more influenced by variations of SST in the Atlantic Ocean than by the same variations in the Pacific Ocean. Consequently, it has been observed a higher concentration of significant levels in the Atlantic (TNAI and TSAI) in relation to those measured in the Pacific $(1+2,3,3.4,4$, ION, IOS). These correlations amounted to $21 \%$ of the total correlated.

During evaluation procedures in the Pacific, ElNiño regions were analyzed, such as those in the eastern parts (Costa del Peru), central and west (near the Australian continent). The only regions with negative significant correlations that confirmed little influence of SST in intense rainfall (positive trend), were: a) (Niño $1+2)$ in annual precipitation with percentiles above $99 \%$; b) (ION), annual rainfall above $50 \mathrm{~mm}$; c) (IOS), with rainfall above the median annual maximum daily precipitation and above $50 \mathrm{~mm}$.

Although most Pacific SST anomalies do not relate significantly to the maximum extreme precipitation in the Sub-basin 39, the negative correlation coefficients, near the coast of Peru (Nino $1+2)$ exhibit a descending branch, with cold water and high pressure, inhibiting the formation of clouds. This condition maintains the Walker cell unchanged pointing towards a typical case of La Niña, mainly on the wetter areas of the Sub-basin 39, especially along the Litoral and Zona da Mata.

In the Atlantic Ocean, all important correlations demonstrate that the SST anomalies as measured on the areas above (TNAI) and below (TSAI) the Equator give rise to a negative phase dipole (Hadley cell). Under such conditions, the South Atlantic waters turn warmer with more intensified trade winds, pushing the position of the ITCZ further south, favoring effectively the occurrence of rainfall in the region, causing both the coming of continuous wet days and maximum extreme rainfall in the NEB and in the Sub-basin 39.

Considering this approach, it has been assumed that the influence of both Pacific and Atlantic Ocean's surface thermal variations may cause the occurrence of maximum extreme events which extend on to the wetlands' rainy season (Litoral and Zona da Mata) in the Sub-basin 39. On the other hand, the influence of the dipole is more decisive than that of ENOS. However, SECTMA (PERNAMBUCO, 2006) argues that there are other systems that also act as integral parts of these extremes, especially the wavelike system disturbances coming from the east (easterly waves). These have been the cause of major storms in the region, such as the June 2010 floods in Pernambuco and Alagoas. As the ITCZ acts from February to May in rainy years, easterly waves turn up from May to August (PERNAMBUCO, 2006).

Table 2. Correlations between the regional indices with positive trends and SST.

\begin{tabular}{lcccccccc}
\hline \multirow{2}{*}{$\begin{array}{l}\text { Regionais } \\
\text { index }\end{array}$} & \multicolumn{3}{c}{ El Niño / Southern Oscillation - Equatorial Pacific Ocean } & \multicolumn{3}{c}{ Atlantic Ocean Dipole } \\
\cline { 2 - 8 } & Niño 1+2 & Niño 3 & Niño 3.4 & Niño 4 & ION & IOS & TNAI \\
\hline PRCPTOT & -0.167 & -0.111 & -0.087 & -0.026 & -0.169 & +0.119 & $-0.227^{* * *}$ & $+0.213^{* *}$ \\
RMedmm & -0.182 & -0.139 & -0.093 & +0.012 & -0.166 & $+0.211^{* * *}$ & +0.027 & $+0.280^{* *}$ \\
Rx1day & -0.125 & -0.024 & +0.040 & +0.161 & -0.054 & +0.081 & +0.113 & $+0.219^{* * *}$ \\
Rx5day & -0.128 & -0.052 & +0.001 & +0.076 & -0.060 & +0.124 & +0.174 & +0.134 \\
SDII & -0.021 & +0.026 & +0.045 & +0.093 & -0.034 & -0.049 & $-0.219^{* * *}$ & $+0.262^{* *}$ \\
R10mm & -0.169 & -0.136 & -0.143 & -0.090 & -0.184 & +0.203 & -0.188 & $+0.334^{*}$ \\
R50mm & -0.168 & -0.156 & -0.130 & -0.066 & $-0.212^{* * *}$ & $+0.214^{* * *}$ & $-0.267^{* * *}$ & $+0.265^{* *}$ \\
R99P & $-0.225^{* * *}$ & -0.191 & -0.133 & -0.031 & -0.208 & +0.192 & -0.012 & $+0.285^{* *}$ \\
CWD & +0.090 & +0.156 & +0.138 & +0.244 & +0.003 & +0.025 & +0.200 & $+0.442^{*}$ \\
\hline
\end{tabular}

* Significance level 1\%; * Significance level 5\%; *** Significance level 10\% 


\section{TSM influence on the smallest extreme events}

Table 3 shows the Pearson linear correlation coefficients adjusted in between the indices of SST anomalies and the levels of the negative regional trends calculated for the Sub-basin 39. The regional indices Rx1day and Rx5day have not proved negative. Significant statistical correlations represent $36 \%$ of the total correlated, with much higher concentration levels measured in the Pacific $(1+2,3,3.4,4$, ION, IOS) than those found in the indices (TNAI and TSAI) taken in the Atlantic.

Despite the fact that Pearson coefficients varied from 0 to 1 in absolute values, a range from 0.211 to 0.442 with statistical significance was observed. Such order of magnitude is considered normal for correlations of SST indices for the NEB region: as investigated by Santos and Manzi (2011) for the state of Ceará, and by Santos and Brito (2007) for the Brazilian semi-arid and by Araújo and Brito (2011) for Bahia and Sergipe.

Throughout the Pacific evaluation, all regions of El Niño were analyzed. Despite the fact that SST anomalies are more correlated to the Pacific near the coast of Peru (Niño $1+2)$, the negative coefficients resulting from correlations with regional rainfall of negative trends reveal a downward branch, as it happens to the branch established by regional rainfall with positive trends in the wetlands, maintaining the same behavior of the Walker cell, which points towards a La Niña condition.

In the Atlantic dipole, important correlations have demonstrated that the SST anomalies observed below the equator (TSAI), where the water is cooler, influence the positioning of the ITCZ further north as a result of an intensification of trade winds coming from the Northeast. This inhibits cloud formation and favors the occurrence of severe and prolonged droughts in the semi-arid regions of the Sub-basin 39, as observed in the Middle Capibaribe and around the São Francisco basin.

All investigations have demonstrated that the occurrence of extreme minimum rainfall in the Sub-basin 39 does not depend solely on ENSO, since important correlations do not reveal ElNiño episodes. Therefore, it is most evident that severe and prolonged droughts in semi-arid areas are really influenced by the Atlantic dipole - entirely unfavorable to rainfall in this region.

The relation between the anomalous patterns of the Atlantic SST and the NEB climate was initially considered by Serra (1941) and then by Hastenrath and Heller (1977). The atmospheric circulation anomalies induced by the spatial distribution of SST in both the Equatorial Pacific and in the Tropical Atlantic define the latitudinal position of the ITCZ, influencing, in this way, rainfall distribution over the Atlantic basin and northern South America (HASTENRATH, 1984; NOBRE; SRUKLA 1996).

Kayano and Andreoli (2006) examined the SST variability associated to extreme weather (droughts and floods) on the NEB. Analyses indicated that the inter-annual climate variations in the $\mathrm{NEB}$ are far more related with the SST variability in the South Atlantic than with the tropical Pacific.

Moura et al. (2009) correlated the precipitation (March-June) over the eastern sector of the NEB with ocean SST anomalies. The analyses showed the influence of the Atlantic and the Pacific on rainfalls over the eastern sector. However, the highest correlation was that of the Atlantic. In the eastern Pacific Ocean, negative correlations indicated the presence of Walker cell descending branches.

Mendonça and Danni-Oliveira (2007) observed that during El Niño, droughts of varying intensities during the rainy season (February to May) in the north central band NEB were most predictable. Alves (2012), when analyzing precipitation interactions with thermal patterns of tropical oceans in the NEB, noted that the inter-annual rainfall variability, particularly over the northern sector, revealed that a decrease in rainfall had been affected by the ENSO cycle and by the phases of the SST dipole over the Tropical Atlantic.

To the North of the Sub-basin 39, Santos and Brito (2007) found correlations with statistical importance in the States of Paraíba and Rio Grande do Norte. Among other results, it was observed that extreme rainfall in the NEB was attributed to SST anomalies, a fact that explains the influence of ENSO. Likewise, when analyzing the dipole of the Atlantic, it became evident that the SST positive anomaly north of the equator, caused the ITCZ to move northwardly, inhibiting rainfall events and increasing drought in these two States.

Santos and Manzi (2011) have also mentioned some similar results to the North - this time, in the State of Ceará. By analyzing various indexes, the authors observed an increase in SST anomalies in the Pacific Ocean and in the North Atlantic Ocean, inhibiting rainfall events and increasing the occurrence of droughts in Northern Ceará, due to a southern shifting of the ITCZ towards north.

Table 3. Correlations between the regional indices with negative trends and SST.

\begin{tabular}{|c|c|c|c|c|c|c|c|c|}
\hline \multirow{2}{*}{$\begin{array}{l}\text { Regionais } \\
\text { index }\end{array}$} & \multicolumn{6}{|c|}{ E1 Niño / Southern Oscillation - Equatorial Pacific Ocean } & \multicolumn{2}{|c|}{ Atlantic Ocean Dipole } \\
\hline & Niño $1+2$ & Niño 3 & Niño 3.4 & Niño 4 & ION & IOS & TNAI & TSAI \\
\hline PRCPTOT & $-0.406^{*}$ & $-0.330^{*}$ & $-0.240^{* * *}$ & $-0.232^{* * *}$ & -0.123 & +0.188 & -0.114 & $-0.234^{* * *}$ \\
\hline RMedmm & $-0.239^{* * *}$ & -0.184 & -0.127 & -0.121 & -0.044 & +0.076 & +0.020 & -0.231 \\
\hline Rx1day & - & - & - & - & - & - & - & - \\
\hline Rx5day & - & - & - & - & - & - & - & - \\
\hline SDII & $-0.303^{* *}$ & $-0.262_{* *}$ & -0.183 & $-0.259^{* *}$ & -0.015 & $+0.216^{* * *}$ & -0.133 & $-0.399^{* *}$ \\
\hline $\mathrm{R} 10 \mathrm{~mm}$ & $-0.360^{*}$ & $-0.296_{* *}$ & $-0.213^{* * *}$ & $-0.228^{* * *}$ & -0.092 & +0.120 & $-0.287^{* *}$ & $-0.301^{* *}$ \\
\hline $\mathrm{R} 50 \mathrm{~mm}$ & $-0.218^{* * *}$ & -0.185 & -0.149 & -0.151 & -0.055 & +0.106 & +0.098 & -0.196 \\
\hline R99P & $-0.238^{* * *}$ & -0.181 & -0.130 & -0.116 & -0.040 & +0.081 & +0.109 & -0.157 \\
\hline CWD & $-0.285^{* *}$ & -0.176 & -0.097 & -0.080 & -0.067 & +0.012 & -0.200 & -0.282 \\
\hline
\end{tabular}

* Significance level 1\%;** Significance level $5 \%$;*** Significance level 10\% 
South of Sub-basin 39, in the States of Bahia and Sergipe, Araújo and Brito (2011) noticed that the SST in both the Pacific and Atlantic Oceans influences precipitation over the area under investigation. They observed as well that both the ENSO and the Atlantic Dipole exert related influences on the NEB climate.

The above mentioned studies reinforce that the eastern NEB, where the Sub-basin 39 is located, suffers no significant influence of the ElNiño events (La Niña) due to its geographical location. The authors agree that the position of the ITCZ is by far the best indicator of extreme rainfall events in the NEB.

\section{CONCLUSIONS}

In the Sub-basin 39, the Atlantic Dipole should be taken as the most important ocean-atmospheric interaction system for determining the behavior of daily extreme precipitation events. However, the ElNiño Southern Oscillation (ENSO) phenomenon does not have an important impact on these same events, probably due to the geographical position of the region under investigation.

In the case of maximum extreme events, the little influence of La Niñ in addition to that of the Atlantic Dipole favorable to the formation of clouds, develops a decisive mix regarding the occurrence of rainy years occurrences. On the other hand, in minimum extreme events, the little influence of ElNiño together with an Atlantic Dipole favorable to droughts, can determine the occurrence of dry years.

\section{ACKNOWLEDGEMENTS}

The authors would like to thank the State Company for the Prospection of Mineral Resources (CPRM), the Federal University of Pernambuco (UFPE), the Rural Federal University of Pernambuco (UFRPE), the Pernambuco State Agency of Water and Climate (APAC), the National Institute of Meteorology (INMET), the Meteorological Service of Canada (MSC), the project REHIDRO 1830/FINEP, and the National Council for Scientific and Technological Development (CNPq) for granting us with PQ.

\section{REFERENCES}

ALVES, J. M. B. Recentes variações climáticas no Nordeste do Brasil com ênfase à precipitação: relações com o ENOS, dipolo de temperatura da superfície do mar no Atlântico tropical e a oscilação decadal do Pacífico. Revista de Geografia, v. 29, n. 3, p. 147-166, 2012. Available from: <http://www.revista.ufpe.br/ revistageografia/index.php/revista/article/view/509/469>. Access on: 03 aug. 2015.

ARAÚJO, W. S.; BRITO, J. I. B. Índices de tendências de mudanças climáticas para os estados da Bahia e Sergipe por meio de índices pluviométricos diários e sua relação com TSM do Pacífico e Atlântico. Revista Brasileira de Meteorologia, v. 26, n. 4, p. 541-554, 2011. Available from: < http:/www.scielo.br/pdf/rbmet/v26n4/ a04v26n4.pdf>. Access on: 16 sept. 2015.

ASSIS, J. M. O.; SOBRAL, M. C. M.; SOUZA, W. M. Análise de detecção de variabilidades climáticas com base na precipitação nas bacias hidrográficas do Sertão de Pernambuco. Revista Brasileira de Geografia Física, v. 3, p. 630-645, 2012. Available from: <http: //www. revista.ufpe.br/rbgfe/index.php/revista/article/ viewFile/433/307>. Access on: 03 aug. 2015.

ASSIS, J. M. O.; SOBRAL, M. G. M. Análise de detecção de tendências no padrão pluviométrico na bacia hidrográfica do rio Capibaribe. Revista Brasileira de Geografia Física, v. 2, p. 320-331, 2012. Available from: <http://www.revista.ufpe.br/rbgfe/index. php/revista/article/view/309/293 > . Access on: 03 aug. 2015.

CAVALCANTI, I. F. A.; FERREIRA, N. J.; SILVA, M. G. A. J.; DIAS, M. A. F. S. Tempo e clima no Brasil. São Paulo: Oficina de Texto, 2009.

FARIAS, R. F. L.; NÓBREGA, R. S. Tendência espacial e temporal da precipitação pluviométrica em Pernambuco: mudanças climáticas e impactos ambientais. Organização J. D. Galvíncio. Recife: Ed. Universitária UFPE, 2010. chap. 15.

FERrEIRA, A. G.; MELLO, N. G. S. Principais sistemas atmosféricos atuantes sobre a região Nordeste do Brasil e a influência dos oceanos Pacífico e Atlântico no clima da região. Revista Brasileira de Climatologia, v. 1, n. 1, p. 15-28, 2005. http:// dx.doi.org/10.5380/abclima.v1i1.25215.

HASTENRATH, S. Interannual variability and annual cycle: mechanisms of circulation and climate in the tropical Atlantic. Monthly Weather Review, v. 112, n. 6, p. 1097-1107, 1984. http:// dx.doi.org/10.1175/1520-0493(1984)112<1097:IVAACM>2.0.CO;2.

HASTENRATH, S.; HELLER, L. Dynamics of climatic hazards in north-east Brazil. Quarterly Journal of the Royal Meteorological Society, v. 110, p. 411-425, 1977. http://dx.doi.org/10.1002/qj.49711046407.

IBGE - INSTITUTO BRASILEIRO DE GEOGRAFIA E ESTATÍSTICA. Mapas temáticos e murais. Rio de Janeiro, 2014. Available from: <http://geoftp.ibge.gov.br/mapas_tematicos/ mapas_murais/>. Access on: 22 sept. 2014.

IPCC - INTERGOVERNMENTAL PANEL ON CLIMATE CHANGE. The Working Group I contribution to the IPCC's Fifth Assessment Report (AR5). The physical science basis. Geneva, 2013. Available from: < https://www.ipcc.ch/report/ar5/wg1/>. Access on: 22 sept. 2014.

JIANG, F.; HU, R. J.; WANG, S.-P.; ZHANG, Y.-W.; TONG, L. Trends of precipitation extremes during 1960-2008 in Xinjiang, the Northwest China. Theoretical and Applied Climatology, v. 111, n. 1-2, p. 133-148, 2013. http://dx.doi.org/10.1007/s00704-012-0657-3.

KAYANO, M. T.; ANDREOLI, R. V. As relações entre as anomalias de precipitação no Nordeste do Brasil e do El Niño-Oscilação Sul. Journal of Geophysical Research, v. 111, p. 1-11, 2006.

MARCUZZO, F. F. N.; ROMERO, V. Influência do El Niño e La Niña na precipitação máxima diária do estado de Goiás. Revista 
Brasileira de Meteorologia, v. 28, n. 4, p. 429-440, 2013. http://dx.doi. org/10.1590/S0102-77862013000400009.

MARENGO, J. A.; ALVES, L. M.; BESERRA E. A.; LACERDA F. F. Recursos hídricos em regiões áridas e semiáridas. Variabilidade e mudanças climáticas no semiárido brasileiro. Campina Grande: Instituto Nacional do Semiárido, 2011. chap. 13.

MENDONÇA, F.; DANNI-OLIVEIRA, I. M. Climatologia: noções básicas e climas do Brasil. São Paulo: Oficina de Textos, 2007.

MENEZES, H. E. A.; BRITO, J. I. B.; SANTOS, C. A. C.; SILVA, L. L. A relação entre a temperatura da superfície dos oceanos tropicais e a duração dos veranicos no estado da Paraíba. Revista Brasileira de Meteorologia, v. 23, n. 2, p. 152-161, 2008. http://dx.doi. org/10.1590/S0102-77862008000200004.

MOURA, G. B. A.; ARAGÃO, J. O. R.; MELO, J. S. P.; SILVA, A. P. N.; GIONGO, P. R.; LACERDA, F. F. Relação entre a precipitação do leste do Nordeste do Brasil e a temperatura dos oceanos. Revista Brasileira de Engenharia Agrícola e Ambiental, v. 13, n. 4, p. 462-469, 2009. http://dx.doi.org/10.1590/S1415-43662009000400014.

NAGUETTINI, M.; PINTO, E. J. A. Hidrologia estatística. Belo Horizonte: CPRM-Serviço geológico do Brasil, 2007.

NOAA - NATIONAL OCEANIC AND ATMOSPHERIC ADMINISTRATION. Boulder, 2014. Available from: <http:/ / www.esrl.noaa.gov/psd/data/climateindices/list/>. Access on: 16 sept. 2014.

NOBRE, P.; SRUKLA, J. Variations of sea surface temperature, wind stress, and rainfall over the tropical Atlantic and South America. Journal of Climate, v. 9, n. 10, p. 2464-2479, 1996. http://dx.doi. org/10.1175/1520-0442(1996)009<2464:VOSSTW>2.0.CO;2.

PERNAMBUCO. Secretaria de Ciências, Tecnologia e Meio Ambiente de Pernambuco - SECTMA. Atlas de Bacias Hidrográficas de Pernambuco. Recife, 2006.

PINHEIRO, A.; GRACIANO, R. L. G.; SEVERO, D. L. Tendência das séries temporais de precipitação da região sul do Brasil. Revista Brasileira de Meteorologia, v. 28, n. 3, p. 281-290, 2013. http:/ /dx.doi. org/10.1590/S0102-77862013000300005.

SALGUEIRO, J. H. P. B.; PINTO, E. J. A.; MONTENEGRO, S. M. G. L.; SILVA, B. B.; SOUZA, W. M. Tendência de índices pluviométricos na bacia do rio Capibaribe-PE e sua influência na gestão dos recursos hídricos. Revista Brasileira de Geografia Física, v. 7, n. 5, p. 1002-1014, 2014. Available from: < http:/ /www.revista. ufpe.br/rbgfe/index.php/revista/article/view/1156/633>. Access on: 18 aug. 2015.

SANTOS, C. A. C.; BRITO, J. I. Análise dos índices de extremos para o semiárido do Brasil e suas relações com TSM e IVDN. Revista Brasileira de Meteorologia, v. 22, n. 3, p. 303-312, 2007. http:// dx.doi.org/10.1590/S0102-77862007000300003.
SANTOS, C. A. C.; MANZI, A. O. Eventos extremos de precipitação no estado do Ceará e suas relações com a temperatura dos oceanos tropicais. Revista Brasileira de Meteorologia, v. 26, n. 1, p. 157-165, 2011. Available from: http://www.rbmet.org.br/port/revista/ revista_artigo.php?id_artigo=1025. Access on: 21 aug. 2015.

SANTOS, C. A. C.; NEALE, C. M. U.; RAO, T. V. R.; SILVA, B. B. Trends in indices for extremes in daily temperature and precipitation over Utah, USA. International Journal of Climatology, v. 31, n. 12, p. 1813-1822, 2011. http://dx.doi.org/10.1002/joc.2205.

SANTOS, C. A. C.; BRITO, J. I. B.; JUNIOR, C. H. F. S.; DANTAS, L. G. Trends in precipitation extremes over the northern part of Brazil from ERA40 dataset. Revista Brasileira de Geografia Física, v. 4, p. 836-851, 2012a. Available from: <http://www.revista.ufpe. $\mathrm{br} / \mathrm{rbgfe} /$ index.php/revista/article/viewArticle/428>. Access on: 18 aug. 2015.

SANTOS, C. A. C.; SATYAMUITY, P.; SANTOS, E. M. Tendências de índices de extremos climáticos para a região de Manaus-AM. Revista Acta Amazônica, v. 42, n. 3, p. 329-336, 2012b. http://dx.doi. org/10.1590/S0044-59672012000300004.

SANTOS, C. A. C.; SATYAMURTY, P.; GOMES, O. M.; SILVA, L. E. M. G. Variability of extreme climate indices at Rio Claro, São Paulo, Brasil. Revista Brasileira de Meteorologia, v. 27, n. 4, p. 395-400, 2012c. http://dx.doi.org/10.1590/S0102-77862012000400003.

SANTOS, C. A. C.; DANTAS, L. G.; MELO, M. M. M. S.; SANTOS, E. G. Trends in Indices for extremes in daily precipitation over Idaho - USA. Revista Brasileira de Geografia Física, v. 4, p. 852-862, 2012d. Available from: <http://www. revista.ufpe.br/rbgfe/index. php/revista/article/view/435/324>. Access on: 18 aug. 2015.

SANTOS, S. M. S.; ASSIS, J. M. O.; SOUZA, W. M. Tendência de mudanças climáticas na bacia do rio Una, Pernambuco - Brasil. Revista Brasileira de Geografia Física, v. 7, p. 243-257, 2014. Available from: <http://www.revista.ufpe.br/rbgfe/index.php/revista / article/view/630/538>. Access on: 19 aug. 2015.

SERRA, A. B. The general circulation over South America. Bull. of the Am. Quarterly Journal of the Royal Meteorological Society, v. 22, p. 173-179, 1941.

SILVA, R. M.; SANTOS, C. A. G.; MOREIRA, M.; REAL, J. C.; BARBOSA, R. C. Rainfall trends over 40 years in the Cobres river basin, Portugal: variability and impacts. In: KOVACS COLLOQUIUM: HYDROLOGICAL SCIENCES AND WATER SECURITY: PAST, PRESENT AND FUTURE, 11., 2014, Paris, France. Proceedings... UK: IAHS, 2015. (IAHS Publ., 366). Available from: <http://www.proc-iahs.net/366/127/2015/ piahs-366-127-2015.pdf>. Access on: 30 dec. 2015.

SOUSA, A. M. L. S.; ROCHA, E. J. P.; VITORINO, M. I. V.; SOUZA, P. J. O. P.; BOTELHO, M. N. Variabilidade espaçotemporal da precipitação na Amazônia durante eventos ENOS. Revista Brasileira de Geografia Física, v. 8, n. 1, p. 13-24, 2015. Available 
from: <http://www.revista.ufpe.br/rbgfe/index.php/revista/ article/view/849/680>. Access on: 18 aug. 2015.

SOUZA, W. M.; AZEVEDO, P. V. Índice de detecção de mudanças climáticas derivados da precipitação pluviométrica e das temperaturas em Recife-PE. Revista Brasileira de Geografia Física, v. 2, p. 320-331, 2012. Available from: < http://www.revista.ufpe.br/rbgfe/índex. php/revista/article/view/305/272> . Access on: 19 aug. 2015.

WANDERLEY, H. S.; SEDIYAMA, G. C.; JUSTINO, F. B.; ALENCAR, L. P.; DELGADO, R. C.. Variabilidade da precipitação no Sertão do São Francisco, estado de Alagoas. Revista Brasileira de Engenharia Agricola, v. 17, n. 7, p. 790-795, 2013. http://dx.doi. org/10.1590/S1415-43662013000700014.

WANG, H.; CHEN, Y.; CHEN, Z. Spatial distribution and temporal trends of mean precipitation and extremes in the arid region, northwest of China, during 1960-2010. Hydrological Processes, v. 27, n. 12, p. 1807-1818, 2012. http://dx.doi.org/10.1002/hyp.9339.

WANG, W.; SHAO, Q.; YANG, T.; PENG, S.; YU, Z.; TAYLOR, J.; XING, W.; ZHAO, C.; SUN, F. Changes in daily temperature and precipitation extremes in the Yellow River Basin, China. Stochastic Environmental Research and Risk Assessment, v. 27, n. 2, p. 401-421, 2013. http://dx.doi.org/10.1007/s00477-012-0615-8.

WMO - WORLD METEOROLOGICAL ORGANIZATION. Guidelines on Analysis of extremes in a changing climate in support of informed decisions for adaptation. Geneva, 2009. (World Climate Data and Monitoring Programme, 72). Available from: <http://www. wmo.int/pages/prog/wcp/wcdmp/documents/WCDMP_72_ TD_1500_en_1.pdf $>$. Access on: 15 sept. 2015.
ZHANG, X.; YANG. F. RClimdex (1.0): user guide. Ontario: Climate Research Branch Environment Canada, 2004. 22 p. Available from: <etccdi.pacificclimate.org/RClimDex/RClimDexUserManual. doc $>$. Access on: 15 sept. 2015.

\section{Authors contributions}

João Salgueiro: Paper conception, definition and implementation of the methodology, bibliographical research, analysis and conclusions from the results, writing and preparation of figures and tables.

Eber Pinto: Contribution in the paper conception, implementation of the methodology, and analysis and completion of the results.

Suzana Montenegro: Contribution in the paper conception, analysis and completion of results and the correction of language translation.

Bernardo Barbosa: Contribution in the paper conception, implementation of the methodology, analysis and completion of the results and the correction of language translation.

Werônica Meira: Contribution in the paper conception, implementation of the methodology, and analysis and completion of the results.

Leidjane Oliveira: Contribution in the paper conception, analysis and completion of the results, and organization and compliance with the jornal guidelines. 